\title{
Liquid-Phase Combinatorial Synthesis of 1,4-Benzodiazepine-2,5-diones as the Candidates of Endothelin Receptor Antagonism
}

\author{
Ming-Fu Cheng and Jim-Min Fang* \\ Department of Chemistry, National Taiwan University, Taipei, Taiwan 106
}

Received April 1, 2003

\begin{abstract}
A library of 1,4-benzodiazepine-2,5-dione dicarboxylate derivatives containing aryl substituents at $N_{1}$ - and $N_{4}$-positions to mimic the amino acid residues of Try-13, Phe-14, and Asp-18 in endothelin-1 is established by using the starting materials of $\alpha$-amino esters, hydroxybenzaldehydes, nitrobenzoyl chlorides, and benzyl bromides in a polyethylene resin-bound liquid-phase synthesis. All of the six synthetic steps are conducted under mild conditions to give the desired products with reasonable yields and purity. The poly(ethylene glycol) support plays as a part of ester linkage that is released at the final step.
\end{abstract}

\section{Introduction}

Endothelins are a group of isopeptides locally produced in various cell types under different physiological stimuli. ${ }^{1}$ Human endothelin-1 (ET-1) is a 21 amino acid peptide that exhibits a potent vasoconstrictor activity, conceivably through its selective interaction with specific receptor subtypes. ${ }^{1}$ Antagonism on the vasoconstrictor endothelin is a potential approach to the treatment of a variety of human diseases including ischemia, hypertension, congestive heart failure, pulmonary hypertension, and subarachnoid hemorrhage. ${ }^{1}$ Among numerous endothelin receptor antagonists, ${ }^{2}$ an indan derivative SB209670 3 (Figure 1) possesses two phenyl substituents to mimic the amino acid residues of Try-13 and Phe-14 in ET-1. The two carboxylic groups in SB209670 also mimic the Asp-18 residue and the $C$ terminus of ET-1, which ligates the $\mathrm{Zn}^{2+}$ ion on binding with endothelin receptor. ${ }^{1}$

In the process of searching for the nonpeptide endothelin antagonists, we speculated that 1,4-benzodiazepine-2,5-dione derivatives bearing appropriate substituents might serve for this purpose. The benzodiazepine core provides a nearly planar platform as that of the indan ring in SB209670. The $N_{1^{-}}$and $N_{4}$-positions may be implanted with the desired aryl substituents. For a better binding affinity with the endothelin receptors, carboxylic groups and other substituents may be introduced to various sites of the benzodiazepine scaffold.

1,4-Benzodiazepine-2,5-dione and its analogues represent an important class of bioactive molecules. ${ }^{4}$ These compounds show remarkable potency in various biological targets, including antithrombotics, antibiotics, and antitumor activities. ${ }^{4}$ Many efforts have been exerted on the synthesis of this class of bioactive compounds. ${ }^{4,5}$ The combinatorial or parallel synthetic approaches are especially noted (Figure 2). ${ }^{5}$ Using polymer-bound reagents, the combinatorial chemistry

* To whom correspondence should be addressed. E-mail: jmfang@ ccms.ntu.edu.tw.
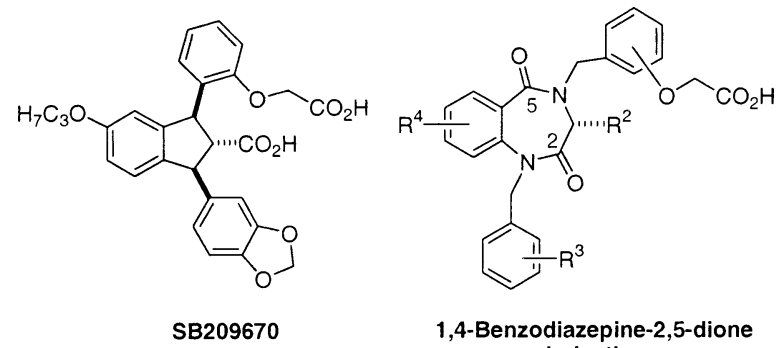

1,4-Benzodiazepine-2,5-dione
derivatives

Figure 1. 1,4-Benzodiazepine-2,5-dione derivatives bearing carboxylic groups are designed to mimic the endothelin receptor antagonist SB209670, which contains two aryl substituents flanking the nearly planar core of indan ring.

has become an efficient tool to build small molecule libraries for accelerating the drug discovery process. ${ }^{6}$

Ellman and co-workers have utilized strategy $\mathrm{A}$ to construct a library of 1,4-benzodiazepine-2,5-diones from three components of anthranilic acids, $\alpha$-amino esters, and alkylating agents. $^{5 a, b}$ Merrifield resin is derivatized by alkylation with the sodium salt of 4-hydroxy-2,6-dimethoxybenzaldehyde, and the resin-bound aldehyde (A3) is linked to $\alpha$-amino esters via reductive amination. Amidation of these resin-bound amino esters with anthranilic acids, followed by cyclization and alkylation, leads to the polymer-bound 1,4benzodiazepine-2,5-dione derivatives (A1). Treatment of A1 with $\mathrm{CF}_{3} \mathrm{CO}_{2} \mathrm{H} / \mathrm{Me}_{2} \mathrm{~S} / \mathrm{H}_{2} \mathrm{O}$ releases the solid support to give 1,4-benzodiazepine-2,5-diones without substitution at the $N_{4}$ position. This solid-phase synthesis thus successfully provides a library of 2508 members. This study does not mention the further alkylation at $N_{4}$-position, which may cause the general problem of regioselectivity in the $\mathrm{N}$ - or $\mathrm{O}$-alkylations in an amide moiety. ${ }^{\text {? }}$

In the strategy devised by Goff and co-workers, ${ }^{5 \mathrm{c}} \alpha$-amino esters (B4) are first reacted with the resin-bound bromoacetate reagent $\mathbf{B 3}$ and then subjected to amidation with 2-azidobenzoyl chlorides (B2). The azido group is reduced by $\mathrm{Ph}_{3} \mathrm{P}$ (Staudinger reaction), and the intermediate is heated to $130{ }^{\circ} \mathrm{C}$ to effect an aza-Wittig reaction. Hydrolysis of the 
A.
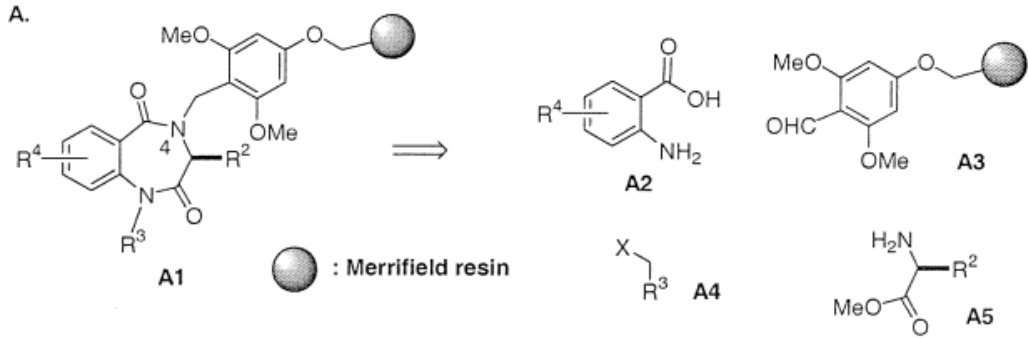

B.

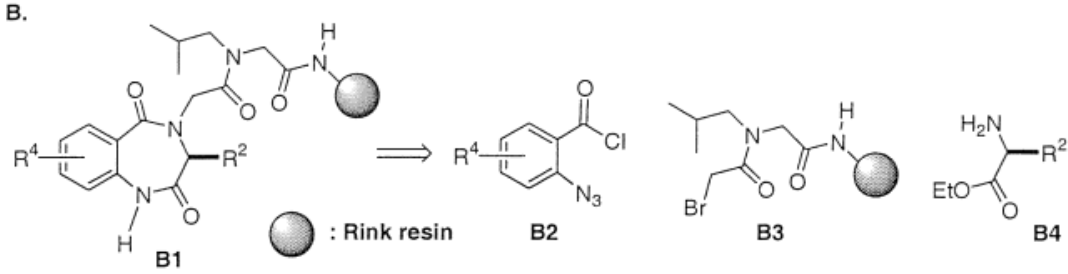

C.

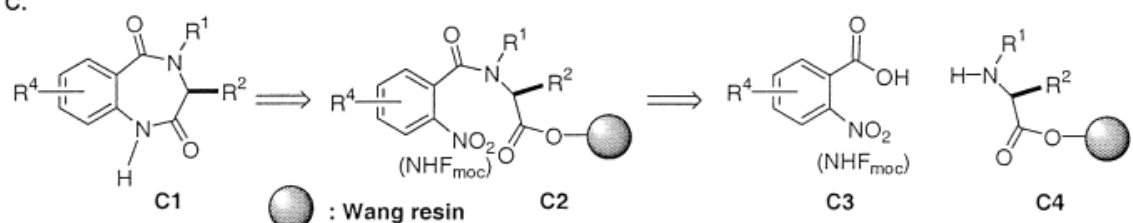

D.
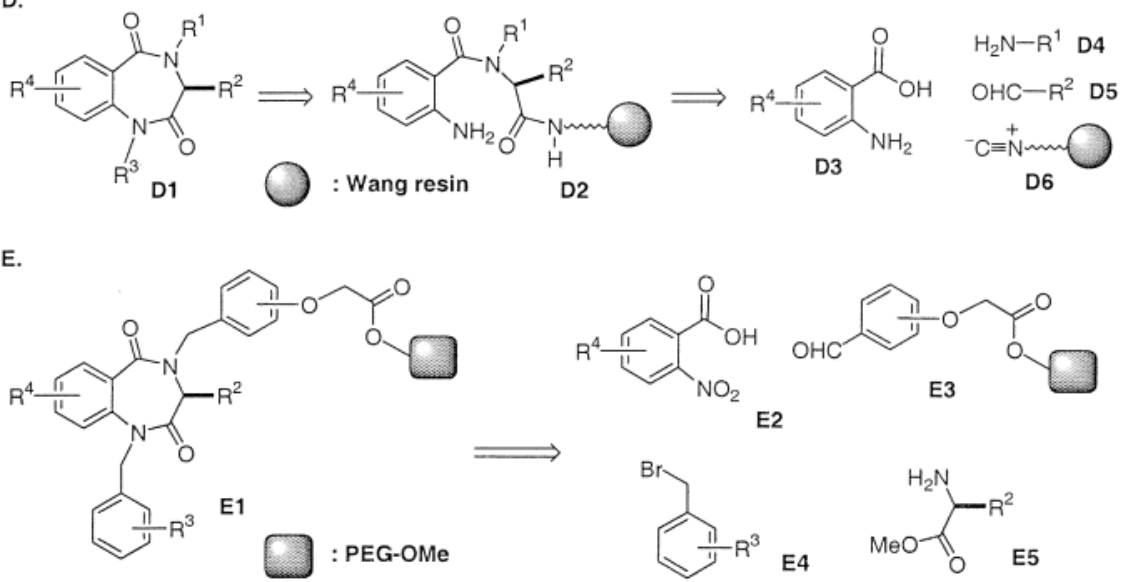

Figure 2. Strategies for combinatorial syntheses of 1,4-benzodiazepine-2,5-dione libraries. Strategy A, see refs 5a,b; strategy B, see ref 5c; strategy $\mathrm{C}$, see ref 5d; strategy D, see refs 5e,f; and strategy E, our present study.

iminoether intermediate and cleavage of the Rink resin are achieved concomitantly by treatment with an acid $\left(\mathrm{CF}_{3} \mathrm{CO}_{2} \mathrm{H} /\right.$ $\left.\mathrm{H}_{2} \mathrm{O}\right)$ to afford the desired 1,4-benzodiazepine-2,5-diones.

The $\alpha$-amino esters derivatized with Wang resin $(\mathbf{C 4})$ are used by Mayer and co-workers to react with 2-nitrobenzoic acid or Fmoc-protected anthranilic acid, giving amides C2 (strategy C). ${ }^{5 \mathrm{~d}}$ This synthetic strategy has an advantage on the concurrent release of the resin support during the cyclization step to form 1,4-benzodiazepine-2,5-diones.

Strategy D shows the synthetic routes carried out by the research groups of Hulme ${ }^{5 \mathrm{e}}$ and Kennedy. ${ }^{5 \mathrm{f}}$ The Wang resinbound isonitriles (D6) are applied to combine with appropriate amines, aldehydes, and anthranilic acids (Ugi four component reaction), giving diamides D2. The terminal amide group (bound to Wang resin) is selectively activated as imidates, which can be substituted by $\mathrm{MeONa}$ to give the corresponding methyl esters for a subsequent lactamization to give 1,4-benzodiazepine-2,5-diones.

All of the above-mentioned methods reside on using solid supports (Merrifield, Rink, and Wang resins) to achieve the combinatorial syntheses of 1,4-benzodiazepine-2,5-diones. In our present study (strategy E), we considered using the liquid-phase synthesis ${ }^{6 n-v}$ as an alternative method to construct a library of 1,4-benzodiazepine-2,5-diones. In comparison with solid-phase synthesis, the liquid-phase synthesis is conducted in a homogeneous organic media. Thus, monitoring the progress of poly(ethylene glycol) (PEG)-bound liquid-phase reaction and analysis of the product mixture becomes feasible.

As the target 1,4-benzodiazepine-2,5-dione requires an $N_{4}$ aryl substituent with a carboxylic group to mimic the Asp18 residue of ET-1, we deliberately used the PEG-bound benzaldehydes $\mathbf{E 3}$ to couple with $\alpha$-amino esters E5. By this means, the required carboxylic group can be revealed at the final step along with removal of the PEG support. We demonstrate herein this strategy by a liquid-phase synthesis of a small library of 1,4-benzodiazepine-2,5-diones $(\mathbf{1 0 a}-\mathbf{p})$ using $\mathrm{PEG}_{5000}$ monomethyl ether as the support (Scheme 1). 
Scheme 1. Liquid-Phase Synthesis of

1,4-Benzodiazepine-2,5-dione Dimethyl Ester Derivatives in This Study ${ }^{a}$

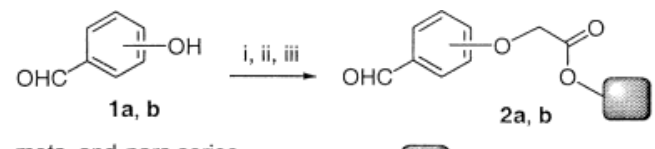

meta- and para-series
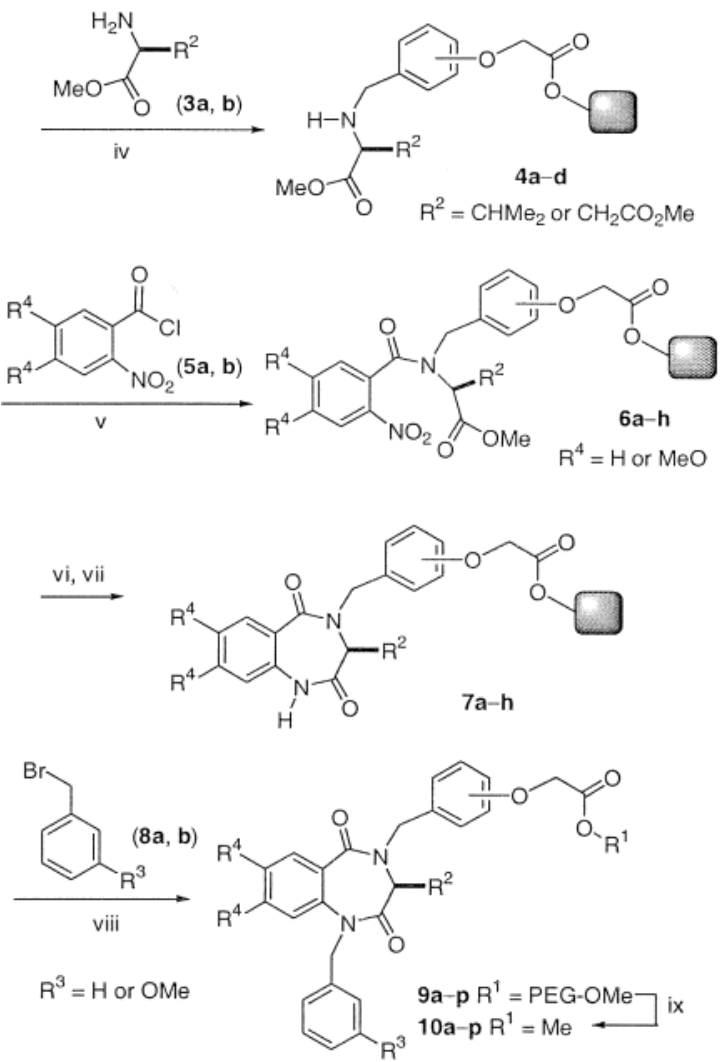

${ }^{a}$ Reagents and conditions: (i) Methyl bromoacetate, $\mathrm{K}_{2} \mathrm{CO}_{3}, \mathrm{CH}_{3} \mathrm{CN}$, reflux $4 \mathrm{~h}, 98 \%$. (ii) $1 \mathrm{~N} \mathrm{NaOH}_{(\mathrm{aq})}, \mathrm{THF}$, room temperature, $2 \mathrm{~h}, 90 \%$. (iii) Monomethoxy-PEG-OH 5000 , DCC, DMAP, $\mathrm{CH}_{2} \mathrm{Cl}_{2}$, room temperature, 23 h. (iv) L-Aspartic acid dimethyl ester hydrochloride or L-valine methyl ester hydrochloride, $\mathrm{NaBH}(\mathrm{OAc})_{3}, \mathrm{NaOAc}, \mathrm{CH}_{2} \mathrm{Cl}_{2}$, room temperature, $5 \mathrm{~h}$. (v) 2-Nitrobenzoyl chloride or 4,5-dimethoxy-2-nitrobenzoyl chloride, $\mathrm{Bu}_{4} \mathrm{NI}$, $\mathrm{K}_{2} \mathrm{CO}_{3}, \mathrm{CH}_{2} \mathrm{Cl}_{2}$, room temperature, $5 \mathrm{~h}$. (vi) $\mathrm{Zn}$, HOAc, room temperature, $2 \mathrm{~h}$. (vii) $\mathrm{CF}_{3} \mathrm{COOH}, \mathrm{CF}_{3} \mathrm{COONa}, \mathrm{CH}_{3} \mathrm{CN}$, room temperature, $13 \mathrm{~h}$. (viii) Benzyl bromide or 3-methoxybenzyl bromide, $\mathrm{Cs}_{2} \mathrm{CO}_{3}, \mathrm{DMF}$, room temperature, 2 h. (ix) $\mathrm{Na}_{2} \mathrm{CO}_{3}, \mathrm{MeOH}$, room temperature, 5 min.

\section{Results and Discussion}

The substitution reaction of methyl bromoacetate with $m$-hydroxybenzaldehyde (1a) or $p$-hydroxybenzaldehyde (1b) was realized in the presence of $\mathrm{K}_{2} \mathrm{CO}_{3}$. After saponification, the resulting carboxylic acids were reacted with $\mathrm{MeO}-\mathrm{PEG}-$ $\mathrm{OH}_{5000}$ resin to form the PEG-bound esters by using dicyclohexylcarbodiimide (DCC) as the activation and dehydration agent. The PEG-bound benzaldehydes $\mathbf{2 a}, \mathbf{b}$ were subjected to reductive amination with $\alpha$-amino esters [aspartic acid dimethyl ester (3a) and valine methyl ester (3b) in this study]. According to the elemental analysis of nitrogen content, the loading of amino esters to the PEG support was nearly quantitative (91-99\% of six measurements). The $N$-(MeO-PEG-bound) amino acid methyl esters $\mathbf{4 a}-\mathbf{d}$ reacted with 2-nitrobenzoyl chloride (5a) or 4,5-dimethyl-2-nitrobenzoyl chloride (5b) to afford the PEG-bound amides $\mathbf{6} \mathbf{a}-\mathbf{h}$. The nitro groups in $\mathbf{6} \mathbf{a}-\mathbf{d}$ were smoothly reduced by
Table 1. Yields and Purities of the 1,4-Benzodiazepine-2,5-dione Dimethyl Ester Derivatives Prepared in This Study (Scheme 1) ${ }^{a}$

\begin{tabular}{cclllcc}
\hline compd & $\mathrm{R}^{1}$ & \multicolumn{1}{c}{$\mathrm{R}^{2}$} & \multicolumn{1}{c}{$\mathrm{R}^{3}$} & \multicolumn{1}{c}{$\mathrm{R}^{4}$} & $\begin{array}{c}\text { crude } \\
\text { yield }(\%)^{b}\end{array}$ & $\begin{array}{c}\text { purity } \\
(\%)^{c}\end{array}$ \\
\hline $\mathbf{1 0 a}$ & $\mathrm{Me}$ & $\mathrm{CH}_{2} \mathrm{CO}_{2} \mathrm{Me}$ & $\mathrm{H}$ & $\mathrm{H}$ & 88 & 68 \\
$\mathbf{1 0 b}$ & $\mathrm{Me}$ & $\mathrm{CH}_{2} \mathrm{CO}_{2} \mathrm{Me}$ & $\mathrm{H}$ & $\mathrm{OMe}$ & 92 & 53 \\
$\mathbf{1 0 c}$ & $\mathrm{Me}$ & $\mathrm{CH}_{2} \mathrm{CO}_{2} \mathrm{Me}$ & $\mathrm{OMe}$ & $\mathrm{H}$ & 89 & 66 \\
$\mathbf{1 0 d}$ & $\mathrm{Me}$ & $\mathrm{CH}_{2} \mathrm{CO}_{2} \mathrm{Me}$ & $\mathrm{OMe}$ & $\mathrm{OMe}$ & 86 & 62 \\
$\mathbf{1 0 e}$ & $\mathrm{Me}$ & $\mathrm{CHMe}_{2}$ & $\mathrm{H}$ & $\mathrm{H}$ & 99 & 67 \\
$\mathbf{1 0 f}$ & $\mathrm{Me}$ & $\mathrm{CHMe}_{2}$ & $\mathrm{H}$ & $\mathrm{OMe}$ & 82 & 62 \\
$\mathbf{1 0 g}$ & $\mathrm{Me}$ & $\mathrm{CHMe}_{2}$ & $\mathrm{OMe}$ & $\mathrm{H}$ & 99 & 77 \\
$\mathbf{1 0 h}$ & $\mathrm{Me}$ & $\mathrm{CHMe}_{2}$ & $\mathrm{OMe}$ & $\mathrm{OMe}$ & 81 & 64 \\
$\mathbf{1 0 i}$ & $\mathrm{Me}$ & $\mathrm{CH}_{2} \mathrm{CO}_{2} \mathrm{Me}$ & $\mathrm{H}$ & $\mathrm{H}$ & 95 & 73 \\
$\mathbf{1 0 j}$ & $\mathrm{Me}$ & $\mathrm{CH}_{2} \mathrm{CO}_{2} \mathrm{Me}$ & $\mathrm{H}$ & $\mathrm{OMe}$ & 95 & 61 \\
$\mathbf{1 0 k}$ & $\mathrm{Me}$ & $\mathrm{CH}_{2} \mathrm{CO}_{2} \mathrm{Me}$ & $\mathrm{OMe}$ & $\mathrm{H}$ & 99 & 76 \\
$\mathbf{1 0 1}$ & $\mathrm{Me}$ & $\mathrm{CH}_{2} \mathrm{CO}_{2} \mathrm{Me}$ & $\mathrm{OMe}$ & $\mathrm{OMe}$ & 95 & 65 \\
$\mathbf{1 0 m}$ & $\mathrm{Me}$ & $\mathrm{CHMe}_{2}$ & $\mathrm{H}$ & $\mathrm{H}$ & 97 & 76 \\
$\mathbf{1 0 n}$ & $\mathrm{Me}$ & $\mathrm{CHMe}_{2}$ & $\mathrm{H}$ & $\mathrm{OMe}$ & 80 & 71 \\
$\mathbf{1 0 0}$ & $\mathrm{Me}$ & $\mathrm{CHMe}_{2}$ & $\mathrm{OMe}$ & $\mathrm{H}$ & 95 & 76 \\
$\mathbf{1 0 p}$ & $\mathrm{Me}$ & $\mathrm{CHMe}_{2}$ & $\mathrm{OMe}$ & $\mathrm{OMe}$ & 80 & 74 \\
\hline
\end{tabular}

${ }^{a}$ Compounds 10a $-\mathbf{h}$ Belong to the meta-series, whereas compounds $10 \mathbf{i}-\mathbf{p}$ Belong to para-series. ${ }^{b}$ The crude yield of $\mathbf{1 0 a}-\mathbf{p}$ in six step liquid-phase reactions (steps iv-ix). ${ }^{c}$ The purity of $10 \mathbf{a}-\mathbf{p}$ after cleavage of the PEG support with $\mathrm{Na}_{2} \mathrm{CO}_{3}$.

zinc powder (HOAc, room temperature, $2 \mathrm{~h}$ ), and the resulting anilines were treated with $\mathrm{CF}_{3} \mathrm{CO}_{2} \mathrm{H} / \mathrm{CF}_{3} \mathrm{CO}_{2} \mathrm{Na}$ at room temperature for $13 \mathrm{~h}$ to give the PEG-bound 1,4benzodiazepine-2,5-diones $\mathbf{7} \mathbf{a}-\mathbf{h}$. For the more reactive substrates $6 \mathbf{e}-\mathbf{h}$, reduction of the nitro group and the subsequent cyclization were conducted in a one pot procedure (zinc powder, HOAc, room temperature, $2 \mathrm{~h}$ ) to give the PEG-bound benzodiazepines $\mathbf{7 e - h}$. Alkylation of $\mathbf{7 a}-\mathbf{h}$ with benzyl bromide (8a) or 3-methoxybenzyl bromide $(\mathbf{8 b})$ was achieved in DMF solution by using $\mathrm{Cs}_{2} \mathrm{CO}_{3}$ as a base, instead of lithium acetanilide used in strategy A. ${ }^{5 a, b}$ On treatment of $\mathbf{9 a}-\mathbf{p}$ with sodium methoxide in methanol at room temperature for a short period ( $<5 \mathrm{~min}$ ), the PEG support was cleaved in a very efficient manner.

Thus, 16 1,4-benzodiazepine-2,5-dione dimethyl ester derivatives $\mathbf{1 0 a}-\mathbf{p}$ were obtained in $80-99 \%$ crude yields by a liquid-phase combinatorial synthesis (Table 1). The high-performance liquid chromatography (HPLC) analyses indicated that the purity of $\mathbf{1 0 a}-\mathbf{p}$, prepared from the PEGbound benzaldehydes $\mathbf{2 a , b}$ in six steps, is around $53-76 \%$ (corresponding to $88-95 \%$ average yield in each synthetic step). This liquid-phase synthesis also showed some notable features. For example, cyclization of $\mathbf{6 a}-\mathbf{h}$ to 1,4-benzodiazepine-2,5-diones $\mathbf{7} \mathbf{a}-\mathbf{h}$ was facilitated by the presence of the $N_{4}$-substituents, which enhanced the cis/trans ratio about these tertiary amides. ${ }^{8}$ All six steps were conducted under mild conditions (short reaction time at room temperature without harsh acid or base) to minimize any possible racemerization. ${ }^{5 b}$ In this synthetic sequence, the PEG support played as not only a capture resin but also a part of ester linkage that was released at the final step. ${ }^{6}$ As the PEG support was readily cleaved by treatment with $\mathrm{MeONa}$ in $\mathrm{MeOH}$ for $10 \mathrm{~s}$, the progress of most reactions (giving compounds $4,6,9$, and 10 ) was easily monitored by thinlayer chromatography (TLC) analyses. The final products $\mathbf{1 0 a}-\mathbf{p}$ were simply purified by silica gel chromatography 
and fully characterized by physical and spectroscopic methods.

The interaction of ET-1 with endothelin receptor is coupled to the increase of intracellular $\mathrm{Ca}^{2+}$ concentration $\left(\left[\mathrm{Ca}^{2+}\right]_{\mathrm{i}}\right)$, a consequence of multistep biological events initiated by G-protein. ${ }^{9}$ According to our preliminary examination, some dicarboxylic acid analogues derived from the dimethyl esters $(\mathbf{1 0 a}-\mathbf{p})$ showed significant inhibition against the ET-1 induced $\left[\mathrm{Ca}^{2+}\right]_{\mathrm{i}}$ increase in the transfected Chinese hamster ovary cells. We are currently engaged in the biological evaluation of various 1,4-benzodiazepine-2,5-diones as the endothelin receptor antagonists.

\section{Experimental Section}

Melting points are uncorrected. ${ }^{1} \mathrm{H}$ NMR spectra were recorded at 300 or $400 \mathrm{MHz} ;{ }^{13} \mathrm{C}$ NMR spectra were recorded at 75 or $100 \mathrm{MHz}$. $\mathrm{CDCl}_{3}\left(\delta_{\mathrm{H}}=7.24\right.$ and $\delta_{\mathrm{C}}=77.0$ (central line of triplet)) was used as an internal standard in ${ }^{1} \mathrm{H}$ and ${ }^{13} \mathrm{C}$ NMR spectra, unless otherwise stated. Mass spectra were recorded at an ionizing voltage of 70 or $20 \mathrm{eV}$. HPLC (Hewlett-Packard 1100) analysis was performed on a vp250/ 10 Nucleosil $100-7$ column $(25 \mathrm{~cm} \times 1 \mathrm{~cm}$ i.d.) with UV detection at $\lambda=254 \mathrm{~nm}$ using the eluents of EtOAc/hexane (3:2 or $4: 1)$ at a flow rate of $1 \mathrm{~mL} / \mathrm{min}$. Merck silica gel $60 \mathrm{~F}$ sheets were used for analytical TLC. Merck silica gel $60 \mathrm{~F}$ glass plates $(20 \mathrm{~cm} \times 20 \mathrm{~cm}$ with $2 \mathrm{~mm}$ thickness $)$ were used for preparative TLC. Column chromatography was performed on silica gel (70-230 mesh) using gradients of EtOAc/hexane as eluents. Tetrahydrofuran (THF) was distilled from sodium benzophenone ketyl under $\mathrm{N}_{2}$. Monomethoxy-PEG-OH was dried by azeotropical removal of water with refluxing acetonitrile.

Methyl (3-Formylphenoxy)acetate and Methyl (4Formylphenoxy)acetate. A mixture of 3-hydroxybenzaldehyde (or 4-hydroxybenzaldehyde, $10.0 \mathrm{~g}, 81.9 \mathrm{mmol}$ ) and $\mathrm{K}_{2} \mathrm{CO}_{3}(34.0 \mathrm{~g}, 245.7 \mathrm{mmol})$ in $\mathrm{CH}_{3} \mathrm{CN}$ was stirred under reflux. After $1 \mathrm{~h}$, methyl bromoacetate was added, and the mixture was allowed to stir under reflux for another $3 \mathrm{~h}$. After the reaction was finished, $\mathrm{CH}_{3} \mathrm{CN}$ was removed, and the residue was extracted with EtOAc $(40 \mathrm{~mL} \times 3)$. The organic layer was dried over $\mathrm{MgSO}_{4}$ and evaporated to give methyl (3-formylphenoxy)acetate [or methyl (4-formylphenoxy)acetate] $(15.6 \mathrm{~g}, 80.3 \mathrm{mmol}, 98 \%)$ as a yellow oil without purification.

(3-Formylphenoxy)acetic Acid and (4-Formylphenoxy)acetic Acid. To a solution of (3-formylphenoxy)acetate [or methyl (4-formylphenoxy)acetate] (14.9 g, $76.8 \mathrm{mmol})$ in THF $(75 \mathrm{~mL})$ was added $1 \mathrm{~N} \mathrm{NaOH}_{(\mathrm{aq})}(45 \mathrm{~mL})$ at $0{ }^{\circ} \mathrm{C}$ for $30 \mathrm{~min}$. The reaction mixture was allowed to stir at room temperature for $1.5 \mathrm{~h}$. After the reaction was completed, 1 $\mathrm{N} \mathrm{NH}_{4} \mathrm{Cl}_{(\mathrm{aq})}(65 \mathrm{~mL})$ was added, and the mixture was extracted with EtOAc $(40 \mathrm{~mL} \times 5)$. The organic layer was dried over $\mathrm{Na}_{2} \mathrm{SO}_{4}$ and purification by recrystallization from EtOAc to give (3-formylphenoxy)acetic acid [or (4-formylphenoxy)acetic acid] $(12.4 \mathrm{~g}, 69.1 \mathrm{mmol})$ as colorless solids.

Methoxy-PEG (3-Formylphenoxy)acetate (2a) and Methoxy-PEG (4-Formylphenoxy)acetate (2b). A solution of methoxy-PEG-OH $\mathrm{OH}_{500}(15.0 \mathrm{~g}, 3.0 \mathrm{mmol})$ was treated with DCC (1.9 g, $9.0 \mathrm{mmol})$, DMAP (367 mg, $3.0 \mathrm{mmol}$ ), and (3-formylphenoxy)acetic acid [or (4-formylphenoxy)acetic acid, $1.6 \mathrm{~g}, 9.0 \mathrm{mmol}]$ in $\mathrm{CH}_{3} \mathrm{CN}(75 \mathrm{~mL})$ at room temperature for $23 \mathrm{~h}$. The mixture was filtered through Celite, and the filtrate was concentrated to about $15 \mathrm{~mL}$. The residue was cooled in an ice bath and triturated with $\mathrm{Et}_{2} \mathrm{O}(105 \mathrm{~mL})$ to give precipitates, which were filtered and washed successively with $\mathrm{Et}_{2} \mathrm{O} / 2$-propanol $(1: 1,60 \mathrm{~mL})$. White powders of PEG-bound ester $\mathbf{2 a}$ (or $\mathbf{2 b}$ ) were obtained by drying under reduced pressure.

$N$-(PEG-Bound) Amino Acid Methyl Esters (4a-d). A mixture of L-aspartic acid dimethyl ester hydrochloride (3a, $553.3 \mathrm{mg}, 2.8 \mathrm{mmol}$ ) [or L-valine methyl ester hydrochloride (3b, $469.4 \mathrm{mg}, 2.8 \mathrm{mmol}$ )] and PEG-bound ester 2a (or 2b) (7.0 g, $1.4 \mathrm{mmol})$ in $\mathrm{CH}_{2} \mathrm{Cl}_{2}(40 \mathrm{~mL})$ was treated with sodium triacetoxyborohydride $(918 \mathrm{mg}, 4.2 \mathrm{mmol})$ and $\mathrm{NaOAc}$ (230 mg, $2.8 \mathrm{mmol}$ ) at $0{ }^{\circ} \mathrm{C}$. The suspension was allowed to warm to room temperature and stirred for $5 \mathrm{~h}$. The progress of reaction was monitored by TLC analysis (EtOAc/hexane, 3:2) of aliquots, which were treated with $\mathrm{NaOMe} / \mathrm{MeOH}$ for $10 \mathrm{~s}$ before analysis. After the reaction was completed, brine $(30 \mathrm{~mL})$ was added, and the mixture was extracted with $\mathrm{CH}_{2} \mathrm{Cl}_{2}(40 \mathrm{~mL} \times 3)$. The organic layer was dried over $\mathrm{MgSO}_{4}$ and concentrated to about $7 \mathrm{~mL}$. The residue was triturated with $\mathrm{Et}_{2} \mathrm{O}(50 \mathrm{~mL})$ to give precipitates. The mixture was cooled in an ice bath; the precipitates were filtered and washed successively with $\mathrm{Et}_{2} \mathrm{O} / 2$-propanol (1: $1,30 \mathrm{~mL}$ ) to give $\mathbf{4 a}-\mathbf{d}$. Elemental analysis (six measurements) showed a nitrogen content of $0.24-0.27 \%$, equivalent to a loading of $0.182 \mathrm{mmol} / \mathrm{g}$ on average $(91-99 \%)$.

Linkage of $N$-(PEG-Bound) Amino Acid Methyl Esters 4a-d with 2-Nitrobenzoyl Chloride or 4,5-Dimethyl-2nitrobenzoyl Chloride, Giving Amides $\mathbf{6 a}-\mathbf{h}$. To a solution of $N$-(PEG-bound) amino acid methyl ester $\mathbf{4 a}$ (or $\mathbf{4 c}, \mathbf{d}$ ) (3.0 $\mathrm{g}, 0.6 \mathrm{mmol})$ in $\mathrm{CH}_{2} \mathrm{Cl}_{2}(20 \mathrm{~mL})$ was added $\mathrm{K}_{2} \mathrm{CO}_{3}(312$ $\mathrm{mg}, 2.4 \mathrm{mmol})$ and $\mathrm{Bu}_{4} \mathrm{NI}(111 \mathrm{mg}, 0.3 \mathrm{mmol})$. 2-Nitrobenzoyl chloride $\mathbf{5} \mathbf{a}, 0.17 \mathrm{~mL}, 1.2 \mathrm{mmol}$ ) [or 4,5-dimethyl2-nitrobenzoyl chloride (5b, $295 \mathrm{mg}, 1.2 \mathrm{mmol}$ )] was then added dropwise into the mixture. The mixture was stirred at room temperature, and the progress of reaction was monitored by TLC analysis (EtOAc/hexane, 3:2) of aliquots, which were treated with $\mathrm{NaOMe} / \mathrm{MeOH}$ for $10 \mathrm{~s}$ before analysis. After $5 \mathrm{~h}$, the mixture was filtered through Celite, and the filtrate was concentrated to about $5 \mathrm{~mL}$. The residue was cooled in an ice bath and triturated with $\mathrm{Et}_{2} \mathrm{O}(30 \mathrm{~mL})$ to give precipitates, which were filtered and washed successively with $\mathrm{Et}_{2} \mathrm{O} / 2$-propanol $(1: 1,25 \mathrm{~mL})$. Yellow powders of PEG-bound amide $\mathbf{6 a}$ (or $\mathbf{6 b}-\mathbf{h}$ ) were obtained by drying under reduced pressure.

PEG-Bound Benzodiazepines 7a-h. PEG-bound amide 6a (or $\mathbf{6 b}-\mathbf{d})(3.0 \mathrm{~g}, 0.6 \mathrm{mmol})$ was dissolved in HOAc (20 $\mathrm{mL})$ and treated with zinc powder (392 $\mathrm{mg}, 6 \mathrm{mmol})$ at room temperature for $2 \mathrm{~h}$. The suspension was filtered through Celite, and the filtrate was evaporated under reduced pressure to give a thick mass of PEG-bound anilines without further purification.

To a solution of the PEG-bound anilines $(3.0 \mathrm{~g}, 0.6 \mathrm{mmol})$ in $\mathrm{CH}_{3} \mathrm{CN}(60 \mathrm{~mL})$ was added trifluoroacetic acid $(1.5 \mathrm{~mL})$ and its sodium salt $(600 \mathrm{mg})$ at room temperature. The mixture was stirred for $13 \mathrm{~h}$, after which $\mathrm{CH}_{3} \mathrm{CN}$ was 
removed under reduced pressure. After addition of brine (25 $\mathrm{mL})$, the mixture was extracted with $\mathrm{CH}_{2} \mathrm{Cl}_{2}(25 \mathrm{~mL} \times 3)$. The organic layer was dried over $\mathrm{MgSO}_{4}$ and concentrated to about $5 \mathrm{~mL}$. The residue was cooled in an ice bath and triturated with $\mathrm{Et}_{2} \mathrm{O}(30 \mathrm{~mL})$ to give precipitates. The precipitates were filtered and washed successively with $\mathrm{Et}_{2} \mathrm{O}$ / 2-propanol $(1: 1,30 \mathrm{~mL})$ to give light yellow solids of the PEG-bound benzodiazepines $7 \mathbf{a}$ (or $\mathbf{7 b}-\mathbf{d}$ ). For the more reactive substrates $\mathbf{6 e}-\mathbf{h}$, reduction of the nitro group and the subsequent cyclization were conducted in a one pot procedure (zinc powder, HOAc, room temperature, $2 \mathrm{~h}$ ) to give the PEG-bound benzodiazepines $\mathbf{7 e}-\mathbf{h}$.

Alkylation of PEG-Bound Benzodiazepines $7 \mathbf{a}-\mathbf{h}$, Giving Benzodiazepines $\mathbf{9 a}-\mathbf{p}$. To a mixture of PEG-bound benzodiazepines $7 \mathbf{a}-\mathbf{h}(1.5 \mathrm{~g}, 0.3 \mathrm{mmol})$ and $\mathrm{Cs}_{2} \mathrm{CO}_{3}(1.5$ $\mathrm{g}, 4.5 \mathrm{mmol})$ in DMF (15 mL) was added benzyl bromide (8a, $0.7 \mathrm{~mL}, 6.0 \mathrm{mmol}$ ) [or 3-methoxybenzyl bromide $(\mathbf{8 b}$, $0.9 \mathrm{~mL}, 6.0 \mathrm{mmol})]$ at room temperature. The progress of reaction was monitored by TLC analysis (EtOAc/hexane, 3:2) of aliquots, which were treated with $\mathrm{NaOMe} / \mathrm{MeOH}$ for 10 $\mathrm{s}$ before analysis. The reaction was completed in $2 \mathrm{~h}$, and DMF was then removed under reduced pressure. After addition of brine $(10 \mathrm{~mL})$, the mixture was extracted with $\mathrm{CH}_{2} \mathrm{Cl}_{2}(10 \mathrm{~mL} \times 3)$. The organic layer was dried over $\mathrm{MgSO}_{4}$ and concentrated to about $5 \mathrm{~mL}$. The residue was cooled in an ice bath and triturated with $\mathrm{Et}_{2} \mathrm{O}(15 \mathrm{~mL})$ to give precipitates, which were filtered and washed successively with $\mathrm{Et}_{2} \mathrm{O} / 2$-propanol $(1: 1,20 \mathrm{~mL})$. Light yellow powders of the PEG-bound benzodiazepines $9 \mathbf{a}-\mathbf{p}$ were obtained by drying under reduced pressure.

1,4-Benzodiazepine-2,5-dione Dimethyl Ester Derivatives $10 \mathbf{a}-\mathbf{p}$. The PEG-bound benzodiazepine $(\mathbf{9 a}-\mathbf{p}, 1.5$ $\mathrm{g}, 0.3 \mathrm{mmol})$ was dissolved in $\mathrm{MeOH}(5 \mathrm{~mL})$ and treated with $\mathrm{Na}_{2} \mathrm{CO}_{3}(31.7 \mathrm{mg}, 0.3 \mathrm{mmol}$ ) at room temperature. The progress of reaction was monitored by TLC analysis (EtOAc/ hexane $=3: 2$ ) of aliquots, which were treated with $\mathrm{NaOMe} /$ $\mathrm{MeOH}$ for $10 \mathrm{~s}$ before analysis. After the reaction was completed (stirring for $5 \mathrm{~min}$ ), the mixture was cooled in an ice bath and triturated with $\mathrm{Et}_{2} \mathrm{O}(5 \mathrm{~mL})$ to give precipitates of $\mathrm{MeO}-\mathrm{PEG}$ resin. The mixture was filtered through Celite, and the filtrate was concentrated under reduced pressure to give a crude product of 1,4-benzodiazepine-2,5-diones (10ap). The purity of these crude products was determined by HPLC analyses. Purification of the crude product was carried out by preparative TLC by elution with gradients of EtOAc/ hexane $(2: 3$ to $3: 2)$.

1-Benzyl-3-(methoxycarbonyl)methyl-4-[3-(methoxycarbonyl)methoxybenzyl]-1,4-benzodiazepine-2,5-dione (10a). Colorless solid, $\mathrm{mp}=52.0-54.0^{\circ} \mathrm{C} ;[\alpha]^{22} \mathrm{D}=+61.8$ $\left(\mathrm{CHCl}_{3}, c=0.59\right)$. IR $(\mathrm{KBr}): 2958,1740,1648 \mathrm{~cm}^{-1} \cdot{ }^{1} \mathrm{H}$ NMR $\left(\mathrm{CDCl}_{3}, 400 \mathrm{MHz}\right): \delta 7.92(1 \mathrm{H}, \mathrm{d}, J=7.6 \mathrm{~Hz}), 7.45-$ $7.41(1 \mathrm{H}, \mathrm{m}), 7.32-7.19(6 \mathrm{H}, \mathrm{m}), 7.13(2 \mathrm{H}, \mathrm{d}, J=7.2 \mathrm{~Hz})$, $6.90(1 \mathrm{H}, \mathrm{d}, J=7.2 \mathrm{~Hz}), 6.86(1 \mathrm{H}, \mathrm{s}), 6.77(1 \mathrm{H}, \mathrm{d}, J=8.0$ $\mathrm{Hz}), 5.22(1 \mathrm{H}, \mathrm{d}, J=16.0 \mathrm{~Hz}), 5.13(1 \mathrm{H}, \mathrm{d}, J=16.0 \mathrm{~Hz})$, $4.91(1 \mathrm{H}, \mathrm{d}, J=16.0 \mathrm{~Hz}), 4.80(1 \mathrm{H}, \mathrm{dd}, J=10.4 \mathrm{~Hz}, 4.4$ $\mathrm{Hz}), 4.60$ (2H, s), $4.31(1 \mathrm{H}, \mathrm{d}, J=16.0 \mathrm{~Hz}), 3.78(3 \mathrm{H}, \mathrm{s})$, $3.56(3 \mathrm{H}, \mathrm{s}), 3.26(1 \mathrm{H}, \mathrm{dd}, J=16.8 \mathrm{~Hz}, 10.4 \mathrm{~Hz}), 2.64(1 \mathrm{H}$, $\mathrm{dd}, J=16.8 \mathrm{~Hz}, 4.4 \mathrm{~Hz}) .{ }^{13} \mathrm{C} \mathrm{NMR}\left(\mathrm{CDCl}_{3}, 100 \mathrm{MHz}\right): \delta$ 170.5 (C), 169.3 (C), 168.8 (C), 168.6 (C), 158.2 (C), 140.1
(C), $139.5(\mathrm{C}), 136.6(\mathrm{C}), 132.5(\mathrm{CH}), 130.9(\mathrm{CH}), 129.9$ $(\mathrm{CH}), 129.3(\mathrm{C}), 128.8(2 \times \mathrm{CH}), 127.3(\mathrm{CH}), 126.5(2 \times$ $\mathrm{CH}), 126.2(\mathrm{CH}), 121.4(\mathrm{CH}), 120.5(\mathrm{CH}), 113.7(\mathrm{CH}), 113.3$ $(\mathrm{CH}), 65.3\left(\mathrm{CH}_{2}\right), 53.0(\mathrm{CH}), 52.3\left(\mathrm{CH}_{3}\right), 52.1\left(\mathrm{CH}_{3}\right), 51.7$ $\left(\mathrm{CH}_{2}\right), 47.0\left(\mathrm{CH}_{2}\right), 31.9\left(\mathrm{CH}_{2}\right)$. HRMS calcd for $\mathrm{C}_{29} \mathrm{H}_{28} \mathrm{~N}_{2} \mathrm{O}_{7}$ $\left(\mathrm{M}+\mathrm{H}^{+}\right)$, 517.1975; found, 517.1978.

Acknowledgment. We thank the National Science Council for financial support.

Supporting Information Available. Physical and spectral data of compounds $\mathbf{1 0 b}-\mathbf{p}$. This material is available free of charge via the Internet at http://pubs.acs.org.

\section{References and Notes}

(1) For recent reviews of endothelin-1, endothelin receptors, and biological activities, see (a) Ohlstein, E. H.; Ruffolo, R. R., Jr. In Endothelin Receptors; Ruffolo, R. R., Jr., Ed.; CRC: Boca Raton, FL, 1995; 1-14. (b) Ohlstein, E. H.; Elliott, J. D.; Feuerstein, G. Z.; Ruffolo, R. R., Jr. Med. Res. Rev. 1996, 16, 365-390. (c) Mateo, A. O.; De Artinano, A. A. Pharmacol. Res. 1997, 36, 339-351. (d) Webb, M. L.; Krystek, S. R., Jr. In Endothelin Receptor Signaling Mechanisms; Pollock, D. M., Highsmith, R. F., Eds.; Springer: Berlin, 1998; pp 67-88. (e) Masaki, T.; Ninomiya, H.; Sakamoto, A.; Okamoto, Y. Mol. Cell. Biochem. 1999, 190, 153-156. (f) Hlavacek, J.; Marcova, R. Collect. Czech. Chem. Commun. 1999, 64, 1211-1252. (g) Goldie, R. G. Clin. Exp. Pharmacol. Physiol. 1999, 26, 145-148. (h) Schiffrin, E. L. Am. J. Hypertension 2001, 14, 83S-89S. (i) Ergul, A. Pharmacotherapy 2002, 22, 54-65. (j) Greenberg, B. H. Congestive Heart Failure 2002, 8, 257-261.

(2) For recent reviews for the synthetic antagonists of endothelin receptors, see (a) Doherty, A. M. In Chemical Structures Approaches to Rational Drug Design; Weiner, D. B., Williams, W. V., Eds.; CRC: Boca Raton, FL, 1995; pp 85-123. (b) Elliott, J. D.; Lago, M. A.; Peishoff, C. E. In Endothelin Receptors; Ruffolo, R. R., Jr., Ed.; CRC: Boca Raton, FL, 1995; pp 79-107. (c) Walsh, T. F. Annu. Rep. Med. Chem. 1995, 30, 91-100. (d) Filep, J. G. Drugs Today 1995, 31, 155-171. (e) Doherty, A. M. Drug Discovery Today 1996, 1, 60-70. (f) Cheng, X.-M.; Ahn, K.; Haleen, S. J. Annu. Rep. Med. Chem. 1997, 32, 61-70. (g) Webb, M. L.; Meek, T. D. Med. Res. Rev. 1997, 17, 17. (h) Tasker, A. S.; Pollock, D. M. In Endothelin Receptor Signaling Mechanisms; Pollock, D. M., Highsmith, R. F., Eds.; Springer: Berlin, 1998; pp 3-15. (i) Elliott, J. D.; Ohlstein, E. H.; Peishoff, C. E.; Ellens, H. M.; Lago, M. A. Pharm. Biotechnol. 1998, 11, 113-129. (j) Benigni, A.; Remuzzi, G. Lancet 1999, 353, 133-138. (k) Dao, H. H.; Moreau, P. Exp. Opin. Invest. Drugs 1999, 8, 1807-1821. (1) Goddard, J.; Webb, D. J. Drugs R\&D 1999, 2, 1-12. (m) Roux, S.; Breu, V.; Ertel, S. I.; Clozel, M. J. Mol. Med. 1999, 77, 364376. (n) Subbiah, V.; Katwa, L. Drugs 2000, 3, 190-197. (o) Boss, C.; Bolli, M.; Weller, T. Curr. Med. Chem. 2002, 9, 349-383. (p) Dasgupta, F.; Mukherjee, A. K.; Gangadhar, N. Curr. Med. Chem. 2002, 9, 549-575.

(3) For SB209670 and the related endothelin receptor antagonists, see (a) Elliott, J. D.; Lago, M. A.; Cousins, R. D.; Gao, A.; Leber, J. D.; Erhard, K. F.; Nambi, P.; Elshourbagy, N. A.; Kumar, C.; Lee, J. A.; Bean, J. W.; DeBrosse, C. W.; Eggleston, D. S.; Brooks, D. P.; Feuerstein, G.; Ruffolo, R. R.; Weinstock, J.; Gleason, J. G.; Peishoff, C. E.; Ohlstein, E. H. J. Med. Chem. 1994, 37, 1553-1557. (b) Clark, W. M.; Tickner-Eldridge, A. M.; Huang, G. K.; Pridgen, L. N.; Olsen, M. A.; Mills, R. J.; Lantos, I.; Baine, N. H. J. Am. Chem. Soc. 1998, 120, 4550-4551. (c) Clark, W. M. Curr. Opin. Drug Discovery Dev. 1999, 2, 565-577. (d) Song, Z. J.; Zhao, M.; Desmond, R.; Devine, P.; Tschaen, D. M.; 
Tillyer, R.; Frey, L.; Heid, R.; Xu, F.; Foster, B.; Li, J.; Reamer, R.; Volante, R.; Grabowski, E. J. J.; Dolling, U. H.; Reider, P. J.; Okada, S.; Kato, Y.; Mano, E. J. Org. Chem. 1999, 64, 9658-9667. (e) Zhang, J.; Didierlaurent, S.; Fortin, M.; Lefrancois, D.; Uridat, E.; Vevert, J. P. Bioorg. Med. Chem. Lett. 2000, 10, 2575-2578. (f) Morimoto, H.; Fukushima, C.; Yamauchi, R.; Hosino, T.; Kikkawa, K.; Yasuda, K.; Yamada, K. Bioorg. Med. Chem. 2001, 9, 255268. (g) Haylor, J. L.; Morcos, S. K.; Nephrology, D. Transplantation 2001, 16, 1336-1337. (h) Niiyama, K.; Mase, T.; Takahashi, H.; Naya, A.; Katsuki, K.; Nagase, T.; Ito, S.; Hayama, T.; Hisaka, A.; Ozaki, S.; Ihara, M.; Yano, M.; Fukuroda, T.; Noguchi, K.; Nishikibe, M.; Ishikawa, K. Bioorg. Med. Chem. 2002, 10, 2461-2470.

(4) For recent articles on the syntheses and bioactivities of 1,4benzodiazepine-2,5-diones, see (a) McDowell, R. S.; Gadek, T. R.; Barker, P. L.; Burdick, D. J.; Chan, K. S.; Quan, C. L.; Skelton, N.; Strumble, M.; Thorsett, E. D.; Tischler, M.; Tom, J. Y. K.; Webb, T. R.; Burnier, J. J. Am. Chem. Soc. 1994, 116, 5069-5076. (b) McDowell, R. S.; Blackburn, B. K.; Gadek, T. R.; McGee, L. R.; Rawson, T.; Reynolds, M.; Robarge, K. D.; Somers, T. C.; Thorsett, E. D.; Tischler, M.; Webb, R. R.; Venuti, M. C. J. Am. Chem. Soc. 1994, 116, 5077-5083. (c) Webb, R. R.; Barker, P. R.; Baier, M.; Reynolds, M. E.; Robarge, K. D.; Blackburn, B. K.; Tichler, M. H.; Weese, K. J. Tetrahedron Lett. 1994, 35, 2113-2116. (d) Armstrong, R.; Combs, A.; Tempest, P.; Brown, D.; Keating, T. Acc. Chem. Res. 1996, 29, 123-131. (e) Ellman, J. A. Acc. Chem. Res. 1996, 29, 9, 132-143. (f) Moroder, L.; Lutz, J.; Grams, F.; Rudolph-Böhner, S.; Ösapay, G.; Goodman, M.; Kolbeck, W. Biopolymers 1996, 38, 295300. (g) Hulme, C.; Cherrier, M.-P. Tetrahedron Lett. 1999, 40, 5295-5299. (h) Cutler, S. J.; Cutler, H. G.; Hamdy, M. K. Proc. Plant Growth Regul. Soc. Am. 27th 2000, 33-41. (i) Osman, A. N.; El-Gendy, A. A.; Omar, R. H.; Wagdy, L.; Omar, A. H. Indian J. Chem., B 2002, 41B, 871-874. (j) Kamal, A.; Nallan, C. L.; Gujjar, R.; Poddutoori, R.; Olepu, S. U.S. Patent 6362331 B1, 2002.

(5) For solid-phase synthesis of 1,4-benzodiazepine-2,5-diones, see (a) Boojamra, C. G.; Burow, K. M.; Ellman, J. A. J. Org. Chem. 1995, 60, 5742-5743. (b) Boojamra, C. G.; Burow, K. M.; Thompson, L. A.; Ellman, J. A. J. Org. Chem. 1997, 62, 1240-1256. (c) Goff, D. A.; Zuckermann, R. N. J. Org. Chem. 1995, 60, 5744-5745. (d) Mayer, J. P.; Zhang, J.; Bjergarde, K.; Lenz, D. M.; Gaudino, J. J. Tetrahedron Lett. 1996, 37, 8081-8084. (e) Hulme, C.; Peng, J.; Morton, G.; Salvino, J. M.; Herpin, T.; Labaudiniere, R. Tetrahedron Lett. 1998, 39, 7227-7230. (f) Kennedy, A. L.; Fryer, A. M.; Josey, J. A. Org. Lett. 2002, 4, 1167-1170.

(6) For recent reviews of combinatorial and parallel syntheses of organic molecules, see (a) Thompson, L. A.; Ellman, J. A. Chem. Rev. 1996, 96, 555-600. (b) Gordon, E. M.; Gallop, M. A.; Patel, D. V. Acc. Chem. Res. 1996, 29, 144154. (c) Balkenhohl, F.; von dem Bussche-Huennefeld, C.; Lansky, A.; Zechel, C. Angew. Chem., Int. Ed. Engl. 1996, 35, 2289-2337. (d) Wilson, S. R., Czarnik, A. W., Eds.; Combinatorial Chemistry, Synthesis and Application; Wiley: New York, 1997. (e) Obrecht, D.; Villalgordo, J. M. In Solid-Supported Combinatorial and Parallel Synthesis of Small-Molecular-Weight Compound Libraries; Baldwin, J. E., Williams, R. M., Eds.; Elsevier Science: Oxford, U.K.,
1998. (f) Kerwin, J. F. In Combinatorial Chemistry and Molecular Diversity in Drug Discovery; Gordon, E. M., Kerwin, J. F., Eds.; Wiley-Liss: New York, 1998; p 475. (g) Booth, R. J.; Hodges, J. C. Acc. Chem. Res. 1999, 32, 18-26. (h) Franzen, R. G. J. Comb. Chem. 2000, 2, 195214. (i) Kirschning, A.; Monenschein, H.; Wittenberg, R. Chem. Eur. J. 2000, 6, 4445-4450. (j) Bhattacharyya, S. Curr. Med. Chem. 2001, 8, 1383-1404. (k) Bräse, S.; Gil, C.; Knepper, K. Bioorg. Med. Chem. 2002, 10, 2415-2437. (1) Ganesan, A. Drug Discovery Today 2002, 7, 47-55. (m) Boyle, N. A.; Janda, K. D. Curr. Opin. Chem. Biol. 2002, 6, 339-346. (n) Sun, C.-M. Comb. Chem. High Throughput Screening 1999, 2, 299-318. (o) Wentworth, P. Trends Biotechnol. 1999, 17, 448-452. (p) Boger, D. L.; Goldberg, J. In Combinatorial Chemistry; Fenniri, H., Ed.; Oxford University Press: Oxford, 2000; pp 303-326. (q) Sugawara, T.; Cork, D. G. In Combinatorial Chemistry; Fenniri, H., Ed.; Oxford University Press: Oxford, 2000; pp 373-400. (r) Bhattacharyya, S. Indian J. Chem., B 2001, 40B, 878890. (s) Weinbrenner, S. Methods Principles Med. Chem. 2000, 9, 22-46. (t) Krepinsky, J. J.; Douglas, S. P. In Solid Support Oligosaccharide Synthesis and Combinatorial Carbohydrate Libraries; Seeberger, P. H., Ed.; Wiley: New York, 2001; pp 175-199. (u) Kirschning, A.; Monenschein, H.; Wittenberg, R. Angew. Chem., Int. Ed. 2001, 40, 650679. (v) Hird, N.; Itoh, K. Yuki Gosei Kagaku Kyokaishi 2002, 60, 508-509.

(7) Blass, B. E.; Burt, T. M.; Liu, S.; Portlock, D. E.; Swing, E. M. Tetrahedron Lett. 2000, 41, 2063-2066.

(8) (a) Dale, J.; Titlestad, K. J. Chem. Soc., Chem. Commun. 1969, 656-659. (b) Titlestad, K. Acta Chem. Scand., B 1977, 31, 641-661. (c) Pastuszak, J.; Gardner, J. H.; Singh, J.; Rich, D. H. J. Org. Chem. 1982, 47, 2982-2987. (d) Jacquier, R.; Lazaro, R.; Raniriseheno, H.; Viallefont, P. Int. J. Pept. Protein Res. 1987, 30, 22-32. (e) Steiner, J. R.; Barnes, C. L. Int. J. Pept. Protein Res. 1988, 31, 212-219. (f) Cavelier-Frontin, F.; Pèpe, G.; Verducci, J.; Siri, D.; Jacquier, R. J. Am. Chem. Soc. 1992, 114, 8885-8890.

(9) (a) Highsmith, R. F.; Blackburn, K.; Schmidt, D. J. Annu. Rev. Physiol. 1992, 54, 257-77. (b) Sakurai, T.; Yanagisawa, M.; Masaki, T. Trends Pharmacol. Sci. 1992, 13, 10-38. (c) Masaki, T.; Yanagisawa, M.; Goto, K. Med. Res. Rev. 1992, 12, 391-421. (d) Lin, W. W.; Kiang, J. G.; Chuang, D. M. J. Neurosci. 1992, 12, 1077-1085. (e) Kohno, M. Clin. Calcium 1994, 4, 1510-1514. (f) Pollock, D. M.; Keith, T. L.; Highsmith, R. F. FASEB J. 1995, 9, 1196-1204. (g) Wenzel, R. R.; Luscher, T. F. In Endothelium Cardiovascular Disease; Luescher, T. F., Ed.; Springer: Berlin, 1995; pp 129-147. (h) Schiffrin, E. L.; Touyz, R. M. J. Cardiovasc. Pharmacol. 1998, 32 (Suppl. 3), S2-S13. (i) Decker, E. R.; Brock, T. A. In Endothelin Receptor Signaling Mechanisms; Pollock, D. M., Highsmith, R. F., Eds.; Springer: Berlin, 1998; pp 131-146. (j) Ruschitzka, F. T.; Noll, G.; Luscher, T. F. J. Clin. Basic Cardiol. 1999, 2, 175-180. (k) Neylon, C. B. Clin. Exp. Pharmacol. Physiol. 1999, 26, 149-153. (1) Triggle, C. R. In Potassium Channels in Cardiovascular Biology; Archer, S. L., Rusch, N. J., Eds.; Kluwer Academic/ Plenum Publishers: New York, 2001; pp 667-689. 